\title{
Nephro-Protective Effect of Wheat Germ Oil on Gentamicin-Induced Acute Nephrotoxicity in Wistar Albino Rat
}

\author{
Lamiaa O. Hafez ${ }^{1 *}$, Fatma A. Ali ${ }^{2}$, Ashraf A. El-Ghoneimy ${ }^{3}$, Magdy I. Abdel-Aziz ${ }^{4}$
}

${ }^{1}$ Department of Pharmacology, Faculty of Veterinary Medicine, Sohag University, 82524, Egypt, ${ }^{2}$ Department of Pathology and Clinical Pathology, Faculty of Veterinary Medicine, Sohag University, 82524, Egypt, ${ }^{3}$ Department of Pharmacology, Faculty of Veterinary Medicine, Qena, South Valley University, 83523, Egypt, ${ }^{4}$ Department of Pharmacology, Faculty of Veterinary Medicine, Kafr Ell-Sheikh University, 33516, Egypt.

\section{Abstract}

Gentamicin (GM) is an aminoglycoside antibiotic that possesses a wide range of anti-microbial activity. Currently, uses of gentamicin are narrowed due to it supposedly induces nephrotoxicity. Therefore, the aim of this study is to evaluate the possible nephron-protective effect of wheat germ oil (WGO), and its antioxidant potential against gentamicin-induced toxicity in Wistar albino rats. Forty rats were randomly assigned to four different groups (Ten animals each); Group I was administered normal saline and acts as a control group. Group II was received WGO at a dose of (3 mg/kg by stomach gavage) daily for the 15 successive days. Group III was administered gentamicin at the dose of $(100 \mathrm{mg} / \mathrm{kg}$ i.p. $)$ daily for 10 successive days. Group IV was given WGO as group II and one hour latter rats were treated with gentamicin as in group III. Rats in group III showed significant increases $(\mathrm{p} \leq 0.05)$ in serum creatinine and blood urea nitrogen (BUN) as well as renal malondialdehyde (MDA) levels together with significant $(\mathrm{p} \leq 0.05)$ reduction in glutathione $(\mathrm{GSH})$ level and catalase (CAT) and superoxide dismutase (SOD) activities. In rats of group IV, creatinine and BUN levels were significantly $(\mathrm{p} \leq 0.05)$ reduced. Furthermore, renal GSH level and CAT and SOD activities were significantly $(\mathrm{p} \leq 0.05)$ increased in comparison to group III. Histopathological examination revealed variable grades of renal tissue alterations ranged from moderate to severe degrees of glomerular atrophy, vascular congestion, hemorrhage, tubular dilatation, necrosis and hyalinization in group III. In contrast, renal tissue in rats of group IV revealed glomerular cellularity of control group, reduction of tubular injury, and decreasing of collagen deposition. Therefore, WGO can effectively decrease the GM-induced renal injury as monitored by lipid peroxidation and histopathological examination.

Keywords: Atrophy, Gentamicin, Nephrotoxicity, Oxidative stress, Wheat Germ Oil (WGO).

DOI: $10.21608 /$ svu. 2019.23582

Received: October 10, 2018

Accepted: December 22, 2018 Published: January 4, 2019

*Corresponding Author: Fatma Abo Zakaib Ali_ E-mail: fatma_ali@vet.sohag.edu.eg

Citation: Hafez et al., Nephro-Protective Effect of Wheat Germ Oil on Gentamicin-Induced Acute Nephrotoxicity in Wistar Albino Rat. SVU-IJVS 2019, 2 (1): 51-67.

Copyright: (C) Hafez et al. This is an open access article distributed under the terms of the creative common attribution license, which permits unrestricted use, distribution and reproduction in any medium provided the original author and source are created.

Competing interest: The authors have declared that no competing interest exists. 


\section{Introduction}

The kidneys are highly vascularized, compound tubular glands, organized principally from numerous, closely packed, uriniferous tubules (Bacha $\mathrm{Jr}$ and Bacha 2012). Kidneys play several critical roles in maintaining fluid and regulating electrolytes balance. Additionally, they produce or activate hormones that are involved in calcium metabolism, erythrogenesis and regulation of blood pressure. Renal dysfunction can adversely alter all these roles (Findlay and Isles 2015).

Gentamicin (GM) is a broad spectrum aminoglycosides antibiotic. It exhibits an antimicrobial activity against the majority of aerobic Gram-negative and Grampositives bacteria (Testa and Tilley 1976). So, it is benefited in the treatment of urinary tract infections (Abrams, Hashim et al. 2017), respiratory system infections and blood, bone and soft tissues diseases of these suggestible bacteria (Altucci, Sapio et al. 1965).Generally, the principal harmful effects of aminoglycoside antibiotics are nephrotoxicity (Smith, Lipsky et al. 1980). GM cytotoxicity takes place in those cell categories wherein the drug accumulates. In kidneys, the epithelial cells in the cortex, primarily in the proximal convoluted tubule (Wu, Connors et al. 2009) and furthermore in the distal and collecting ducts as well (Fujiwara, Shin et al. 2009) are severely affected.

Several medications and strategies have been designed to restrict GM nephrotoxicity (Ali, Rizvi et al. 2003, Nagai and akano 2004, Cekmen, Otunctemur et al. 2013). The principal concentration was on the usage of numerous antioxidant agents including those obtained from medical plants (Ali, Rizvi et al. 2003), safely reacted with free radicals and dismissed the chain reaction earlier before essential molecules are damaged (Lobo, Patil et al. 2010). Wheat germ oil (WGO) is naturally obtained from the wheat kernel germs extraction. It considered an essential source of vital fatty acids, involving oleic, linoleic, linolenic, palmitic and oleic, protein and minerals. In addition, WGO is originally have vitamins $\mathrm{A}, \mathrm{D}$ and $\mathrm{E}$, and also, encompasses vitamins B1, B2, B3,B6 (Abdel Fattah, Fahim et al. 2011). It is also rich in policosanol and octacosanols and dietary fibers and phyto-chemicals; so WGO have an antioxidant property (Irmak and Dunford 2005). WGO considered an excellent source of natural vitamin $\mathrm{E}$, consequently it has antioxidant properties and can reduce oxidative stress (Alessandri, Pignatelli et al. 2006). In addition, it protects cells against the adverse effects of free radicals (Field, Verghese et al. 2008, Barakat, Abbas et al. 2011). Supplementation with WGO caused a great noticeable reduction in plasma malondialdehyde (MDA) and a significant improve in the concentration of vitamins and the antioxidant enzymes (Saleh, Ibrahim et al. 2010). Moreover, It enhanced various biochemical parameters (El-Hameed, Soliman et al. 2013). WGO is curative against lipid peroxidation, oxidative stress and diminutied the inflammatory response stimulated by endotoxin injection in rats (El-Hameed, Soliman et al. 2013).

The present study is designed to evaluate the protective role of WGO against GM-induced alterations in serum biochemical parameters, oxidative assays and morphology of renal tissue in Wistar albino rats.

\section{Materials and Methods}

Drugs and volatile oil: 
Gentamicin was purchased from Memphis Co. under authority of ScheringPlough Corporation /U.S.A. WGO was obtained from Sigma Aldrich Company for chemicals, Cairo, Egypt.

\section{Animals and experimental design}

Animals:

Forty female adult Wistar albino rats (weighing about 150-250 $\mathrm{g}$ and aged from 3-4 months) were obtained from the animal house, Faculty of Medicine, Assuit University and housed in a special wire cages and kept under complete isolated conditions in the animal facilities of Faculty of Veterinary Medicine, Sohag University for two weeks prior to experiment for adaptation. Animals were kept on a 12-hour light, 12-hour dark cycle with ambient temperature of $22-24^{\circ} \mathrm{C}$ and were provided a commercial pelleted feed and water ad libitum. Experimental design and all animal handling procedures were approved by the Research Ethical Committee of the Faculty of Veterinary Medicine, South Valley University, Qena, Egypt (the approval no. 20147). All precautions were taken into consideration to avoid animal suffering.

\section{Experimental design:}

After acclimation, forty rats were randomly assigned to four different isolated groups (Ten animals each); group I was administered normal saline and act as a control group. Group II was received WGO at a dose of $(3 \mathrm{mg} / \mathrm{kg}$ b wt. by stomach gavage) (Barakat, Abbas et al. 2011) daily for 15 successive days. Group III was administered GM at the dose of $(100 \mathrm{mg} / \mathrm{kg} \mathrm{b}$ wt. i.p.) daily for 10 successive days (Khan, Badar et al. 2011). Group IV was given WGO as in group II; one hour latter rats were treated with GM as described in group III.

\section{Methods}

Blood and renal tissue sampling:

Twenty four hours after the last treatment, five rats from each group were used for blood sampling and rats were sacrificed by decapitation and kidneys were rapidly excised from each animal, divided equally and washed with $0.9 \%$ $\mathrm{NaCl}$ solution and distilled water, then blotted using filter paper. One portion was fixed in $10 \%$ neutral buffered formalin for histopathological examination and the other part was kept freeze under $-20^{\circ} \mathrm{C}$ for peroxidation assays. The sampling process performed at the $10^{\text {th }}$ and $15^{\text {th }}$ days of the experiment from each group except for the control group (group I) where all rats were sacrificed at day $10^{\text {th }}$.

\section{Blood samples}

Blood samples were collected from the retro-orbital plexus into centrifuge tubes. Serum was separated after centrifugation at $3000 \mathrm{rpm}$ for 15 minutes. Sera were relocated into dry, clean labeled stoppered tubes, and stored frozen at $-20^{\circ} \mathrm{C}$ for biochemical analysis.

\section{Serum biochemical analyses}

Sera were used for evaluation of serum creatinine (Doolan, Alpen et al. 1962) and blood urea nitrogen (BUN) (Coulombe and Favreau 1963) levels calorimetrically using creatinine and urea kits obtained from (Spectrum Egyptian Company for biotechnology).

\section{Assessment of renal oxidative stress}

\section{Preparation of renal tissue homogenate:}

Renal samples were washed with a phosphate buffered saline (PBS) solution, $\mathrm{pH} 7.4$ including $0.16 \mathrm{mg} / \mathrm{ml}$ heparin to get rid of red blood cells and clots preceding its dissection into specimens. One gram of renal tissue was homogenized with $4 \mathrm{ml} 0.9 \% \mathrm{NaCl}$ and then extracted by centrifuge at $2000 \mathrm{rpm}$ for $20 \mathrm{~min}$. The 
resultant supernatant was transferred into Eppendorf tubes, and preserved at $-80^{\circ} \mathrm{C}$ in a deep freezer until used for various biochemical assays.

Evaluation of the lipid peroxidation and antioxidant enzymes

Lipid peroxidation was evaluated by measurement of MDA in renal tissues using biodiagnostic kit according to methods of (Kei, 1978, Ohkawa et al. 1979).

The non-enzymatic antioxidant biomarker; reduced glutathione (GSH) level was assessed in tissue supernatant colorimetrically using biodiagnostic kit according to the method of (Beutler et al., 1963).

The enzymatic antioxidant biomarkers; catalase (CAT) was evaluated according to (Aebi, 1984) and superoxide dismutase (SOD) according to (Nishikimi, Appaji et al., 1972).

\section{Histological assessment}

The kidney specimens were removed rapidly, fixed in $10 \%$ neutral buffered formalin for $24 \mathrm{~h}$ and imbedded in paraffin wax. Paraffin sections ( $5 \mu \mathrm{m}$ thickness) were afterward stained with Hematoxylin and Eosin (H\&E) (Carleton et al. 1980, Bancroft et al. 1996) and Masson's Trichrome stains (Sereno, Vala et al. 2015).

\section{Statistical analysis}

Results were stated as mean \pm S.E. The measurements gotten from different groups are statistically evaluated using one way ANOVA and independent $t$ test in analysis of data comparing between groups and time using SPSS program.

\section{Result}

\section{Serum biochemical analysis}

Biochemical assays in Wister rats treated with GM, WGO and both are illustrated in table 1 and 2. Rats in group III revealed significant $(\mathrm{p} \leq 0.05)$ increases in creatinine and BUN levels when compared to control group at the 10th and 15 th days post treatment (pt). Meanwhile, rats in group IV provoked significant $(p \leq 0.05)$ decreases in serum BUN and creatinine levels as compared to rats in group III at the 10th and 15th day pt. (Table 1). The effect was significant $(\mathrm{p} \leq 0.05)$ in group III at $15^{\text {th }}$ than at 10 th day in time dependent manner (Table 2).

Table 1: Effects of wheat germ oil (WGO; $3 \mathrm{ml} / \mathrm{kg}$ ), gentamicin (GM; $100 \mathrm{mg} / \mathrm{kg}$ ), and their combination $(\mathrm{WGO}+\mathrm{GM})$ on serum creatinine $(\mathrm{mg} / \mathrm{dl})$ and blood urea nitrogen $(\mathrm{BUN} ; \mathrm{mg} / \mathrm{dl})$ levels in normal and treated rats at $10^{\text {th }}$ and $15^{\text {th }}$ day of experiment. (Mean $\left.\pm \mathrm{SE}\right)(\mathrm{N}=5)$.

\begin{tabular}{|c|c|c|c|c|}
\hline \multirow[t]{2}{*}{ Group } & \multicolumn{2}{|c|}{$\begin{array}{c}\text { Creatinine } \\
\text { (mg/dl) }\end{array}$} & \multicolumn{2}{|c|}{$\begin{array}{c}\text { BUN } \\
\text { (mg/dl) }\end{array}$} \\
\hline & $10^{\text {th }}$ day & $15^{\text {th }}$ day & $10^{\text {th }}$ day & $15^{\text {th }}$ day \\
\hline Control* & \multicolumn{2}{|c|}{$0.77 \pm 0.06^{\mathrm{a}^{*}}$} & \multicolumn{2}{|c|}{$28.40 \pm 2.49^{\mathrm{a}^{*}}$} \\
\hline WGO & $0.72 \pm 0.06^{\mathrm{a}}$ & $0.53 \pm 0.03^{\mathrm{a}}$ & $26.20 \pm 1.93^{\mathrm{a}}$ & $27.00 \pm 1.52^{\mathrm{a}}$ \\
\hline GM & $4.78 \pm 0.54^{\mathrm{c}}$ & $8.28 \pm 0.76^{\mathrm{c}}$ & $88.00 \pm 9.20^{c}$ & $115.20 \pm 4.65^{\mathrm{c}}$ \\
\hline WGO + GM & $1.63 \pm 0.16^{b}$ & $1.35 \pm 0.13^{b}$ & $42.20 \pm 1.50^{b}$ & $39.80 \pm 1.07^{b}$ \\
\hline
\end{tabular}

Values are expressed in Means \pm SE. Values superscripted by different letters within the same column are significantly $(P \leq 0.05)$ different. $*$ In the control group (group I), all rats were sacrificed at day $10^{\text {th }}$. 
Table 2: Comparable effects of wheat germ oil (WGO; 3ml/kg), gentamicin (GM; $100 \mathrm{mg} / \mathrm{kg}$ ), and their combination $(\mathrm{WGO}+\mathrm{GM})$ on serum creatinine $(\mathrm{mg} / \mathrm{dl})$ and blood urea nitrogen $(\mathrm{BUN} ; \mathrm{mg} / \mathrm{dl})$ levels in normal and treated rats at $10^{\text {th }}$ and $15^{\text {th }}$ day of the experiment. (Mean $\left.\pm \mathrm{SE}\right)(\mathrm{N}=5)$.

\begin{tabular}{|c|c|c|c|c|c|c|c|c|}
\hline \multirow[b]{2}{*}{$\begin{array}{c}\text { Day of } \\
\text { sampling }\end{array}$} & \multicolumn{2}{|c|}{ Control* } & \multicolumn{2}{|c|}{ WGO } & \multicolumn{2}{|c|}{ GM } & \multicolumn{2}{|c|}{ WGO + GM } \\
\hline & $\begin{array}{c}\text { Creatinine } \\
(\mathrm{mg} / \mathrm{dl})\end{array}$ & $\begin{array}{c}\text { BUN } \\
(\mathbf{m g} / \mathbf{d l})\end{array}$ & $\begin{array}{c}\text { Creatinine } \\
\text { (mg/dl) }\end{array}$ & $\begin{array}{c}\text { BUN } \\
(\mathbf{m g} / \mathbf{d l})\end{array}$ & $\begin{array}{c}\text { Creatinine } \\
\text { (mg/dl) }\end{array}$ & $\begin{array}{c}\text { BUN } \\
(\mathrm{mg} / \mathrm{dl})\end{array}$ & $\begin{array}{c}\text { Creatinine } \\
\text { (mg/dl) }\end{array}$ & $\begin{array}{c}\text { BUN } \\
(\mathrm{mg} / \mathrm{dl})\end{array}$ \\
\hline $10^{\text {th }}$ day & $0.77 \pm$ & $28.4 \pm$ & $\begin{array}{l}0.72 \pm \\
0.06\end{array}$ & $\begin{array}{l}26.20 \pm \\
1.93^{\mathrm{a}}\end{array}$ & $\begin{array}{l}4.78 \pm \\
0.54^{\mathrm{a}}\end{array}$ & $\begin{array}{l}88.00 \pm \\
9.20^{\mathrm{a}}\end{array}$ & $\begin{array}{l}1.63 \pm \\
0.16^{\mathrm{a}}\end{array}$ & $\begin{array}{l}42.2 \pm \\
1.50^{\mathrm{a}}\end{array}$ \\
\hline $15^{\text {th }}$ day & $0.06^{\mathrm{a}^{*}}$ & $2.49^{\mathrm{a}^{*}}$ & $\begin{array}{l}\mathbf{0 . 5 3} \pm \\
\mathbf{0 . 0 3}^{\mathrm{a}}\end{array}$ & $\begin{array}{l}27.00 \pm \\
1.52^{\mathrm{a}}\end{array}$ & $\begin{array}{l}8.28 \pm \\
0.76^{b}\end{array}$ & $\begin{array}{l}115.2 \pm \\
4.65^{b}\end{array}$ & $\begin{array}{l}1.35 \pm \\
0^{1.13}\end{array}$ & $\begin{array}{l}39.8 \pm \\
1.07^{a}\end{array}$ \\
\hline
\end{tabular}

Means carrying different superscripts within the same column are significantly $(P \leq 0.05)$ different.

* In the control group (group I), all rats were sacrificed at day $10^{\text {th }}$.

Renal lipid peroxidation and antioxidant status:

Rats in group II had a non-significant $(p \leq 0.05)$ increase in MDA levels at the 10 th and $15^{\text {th }}$ day pt. as compared to control group (Table 3). Levels of MDA were significant $(p \leq 0.05)$ higher in group III than those of groups I and II. In contrast, MDA levels in group IV significantly $(\mathrm{p} \leq 0.05)$ decreased when compared to those in group III at the 10th and 15th dpi (Table 3 ). In rats of group III, GSH content and CAT, and SOD activities significantly $(p \leq 0.05)$ increased in lipid peroxidation at 10 and 15 days as compared with group I (Table 3). In contrast, they were significantly $(\mathrm{p} \leq 0.05)$ increased in rats of group IV when compared to group III at the 10th and 15th dpi (Table 3). The effect was much more significant in MDA level at 15th than at 10th day (Table 4). MDA, SOD and GSH parameters were significantly higher at 15th dpi than at 10th dpi in groups III, IV and II, respectively (Table 4).

\section{Histopathological Observations:}

At $10^{\text {th }}$ dpi, tubular and glomerular changes with hyperemia and hemorrhage were found in group III (Fig. 1). Lesions severity ranged from moderate to severe grades. At $15^{\text {th }}$ dpi, lesions were mostly of severe grade in renal tissue of rats in group III (Fig. 2).
Atrophic glomeruli were described affecting less than half of cortical section from the moderate grade (Fig. 1d), while the glomerular atrophy was observed affecting more than half of the cortical region from sever grades (Fig. 2 a, b \& e).

Destruction of glomerular capillaries with leakage of RBCs (Fig. 1 e \& $\mathrm{f}$ and Fig. 2 b) and fibrinoid degeneration, necrosis and hyalization of renal blood vessels were observed in group III (Fig. 2 c). Renal tubular epithelium desquamation, vacuolization inside tubular lumen, tubular dilation with hyaline casts were observed in group III (Fig. 1d \& e and Fig. 2 a). Lymphocytic interstitial infiltration has intensified (Fig. 2 c \& d). All together expressed in a sever grades. Collagen staining was shown in the glomeruli and around the Bowman's capsule (Fig. 1g\&h and Fig.2e\&f) and perivascular, in addition to its diffusely interstitial location (Fig.1h).

In group IV, the renal architecture was less affected than that of group III. Minimal glomerular atrophy, tubular dilatation, swelling, and desquamation (Fig. 1 i \& j). Less inflammatory cell infiltration were observed (Fig. 1 i \& Fig. 2 g). The fibrosis in interstitial decreased in comparison with group III and was mainly limited to periglomerular areas (Fig. $1 \mathrm{j} \&$ Fig. $2 \mathrm{~h}$ ). The fibrosis and renal degenerative changes were improved at $15^{\text {th }} \mathrm{dpt}$. when compared to $10^{\text {th }} \mathrm{dpt}$. 
Table 3: Effects of wheat germ oil (WGO; 3ml/kg), gentamicin (GM; $100 \mathrm{mg} / \mathrm{kg}$ ), and their combination (WGO + GM) on malondialdehyde (MDA; $\mu \mathrm{mol} / \mathrm{mg}$ ), glutathione (GSH; $\mu \mathrm{mol} / \mathrm{g}$ ) levels, catalase (CAT; U/mg) and superoxide dismutase (SOD; U/mg) activities in normal and treated rats at $10^{\text {th }}$ and $15^{\text {th }}$ day of experiment. (Mean $\left.\pm \mathrm{SE}\right)(\mathrm{N}=5)$.

\begin{tabular}{|c|c|c|c|c|c|c|c|c|}
\hline \multirow[t]{2}{*}{ Group } & \multicolumn{2}{|c|}{$\begin{array}{c}\text { MDA } \\
(\mu \mathrm{mol} / \mathbf{m g})\end{array}$} & \multicolumn{2}{|c|}{$\begin{array}{c}\text { CAT } \\
\text { (U/mg) }\end{array}$} & \multicolumn{2}{|c|}{$\begin{array}{c}\text { SOD } \\
(\mathrm{u} / \mathrm{mg})\end{array}$} & \multicolumn{2}{|c|}{$\begin{array}{c}\text { GSH } \\
(\mu \mathrm{mol} / \mathrm{g})\end{array}$} \\
\hline & $10^{\text {th }}$ day & $15^{\text {th }}$ day & $10^{\text {th }}$ day & $15^{\text {th }}$ day & $10^{\text {th }}$ day & $15^{\text {th }}$ day & $10^{\text {th }}$ day & $15^{\text {th }}$ day \\
\hline Control* & \multicolumn{2}{|c|}{$9.06 \pm 0.41^{\mathrm{a}}$} & \multicolumn{2}{|c|}{$4.57 \pm 0.13^{c}$} & \multicolumn{2}{|c|}{$20.10 \pm 1.20^{b}$} & \multicolumn{2}{|c|}{$0.68 \pm 0.05^{b}$} \\
\hline WGO & $8.07 \pm 0.09^{a}$ & $7.86 \pm 0.32^{a}$ & $4.30 \pm 0.22^{b}$ & $4.72 \pm 0.25^{b}$ & $22.40 \pm 1.72^{c}$ & $25.20 \pm 2.22^{b}$ & $0.87 \pm \mathbf{0 . 0 6}^{\mathrm{b}}$ & $1.04 \pm 0.20^{c}$ \\
\hline WGO + GM & $10.80 \pm 0.46^{b}$ & $9.77 \pm 0.40^{\mathrm{a}}$ & $3.40 \pm 0.26^{b}$ & $3.90 \pm 0.12^{b}$ & $16.60 \pm 1.21^{b}$ & $23.60 \pm 1.50^{b}$ & $0.77 \pm 0.04^{b}$ & $0.87 \pm 0.03^{b}$ \\
\hline
\end{tabular}

Values are expressed in Means \pm SE.

Values superscripted by different letters within the same column are significantly $(P \leq 0.05)$ different.

* In the control group (group I), all rats were sacrificed at day $10^{\text {th }}$. 
Table 4: Comparable effects of wheat germ oil (WGO; 3ml/kg), gentamicin (GM; $100 \mathrm{mg} / \mathrm{kg}$ ), and their combination (WGO + GM) on MDA $(\mu \mathrm{mol} / \mathrm{mg}), \mathrm{GSH}(\mu \mathrm{mol} / \mathrm{g})$ levels, CAT $(\mathrm{U} / \mathrm{mg})$ and SOD $(\mathrm{U} / \mathrm{mg})$ activities in normal and treated rats at 10th and 15th day of experiment. (Mean $\pm \mathrm{SE})(\mathrm{N}=5)$.

\begin{tabular}{|c|c|c|c|c|c|c|c|c|c|c|c|c|c|c|c|c|}
\hline \multirow{2}{*}{$\begin{array}{c}\text { Day } \\
\text { of } \\
\text { sampling }\end{array}$} & \multicolumn{4}{|c|}{ Control* } & \multicolumn{4}{|c|}{ WGO } & \multicolumn{4}{|c|}{ GM } & \multicolumn{4}{|c|}{ WGO + GM } \\
\hline & $\underset{(\mu \mathrm{mol} / \mathrm{mg})}{\text { MDA }}$ & $\begin{array}{c}\text { CAT } \\
\text { (U/mg) }\end{array}$ & $\begin{array}{c}\text { SOD } \\
(\mathbf{u} / \mathbf{m g})\end{array}$ & $\underset{(\mu \mathrm{mol} / \mathrm{g})}{\mathbf{G S H}}$ & $\begin{array}{c}\text { MDA } \\
\mu \mathrm{mol} / \mathrm{mg}\end{array}$ & $\begin{array}{c}\text { CAT } \\
\text { (U/mg) }\end{array}$ & $\begin{array}{c}\text { SOD } \\
(\mathbf{u} / \mathbf{m g})\end{array}$ & $\underset{(\mu \mathrm{mol} / \mathrm{g})}{\mathbf{G S H}}$ & $\begin{array}{c}\text { MDA } \\
\mu \mathrm{mol} / \mathrm{mg}\end{array}$ & $\begin{array}{c}\text { CAT } \\
\text { (U/mg) }\end{array}$ & $\begin{array}{c}\text { SOD } \\
\text { (u/mg) }\end{array}$ & $\begin{array}{c}\text { GSH } \\
(\mu \mathrm{mol} / \mathrm{g})\end{array}$ & $\begin{array}{c}\text { MDA } \\
\mu \mathrm{mol} / \mathrm{mg}\end{array}$ & $\begin{array}{c}\text { CAT } \\
\text { (U/mg) }\end{array}$ & $\begin{array}{c}\text { SOD } \\
(\mathbf{u} / \mathbf{m g})\end{array}$ & $\underset{(\mu \mathrm{mol} / \mathrm{g})}{\text { GSH }}$ \\
\hline $10^{\text {th }}$ day & $9.06 \pm$ & $4.57 \pm$ & $20.10 \pm$ & $0.68 \pm$ & $\begin{array}{c}8.07 \pm \\
0.09^{a}\end{array}$ & $\begin{array}{c}4.30 \pm \\
0.22^{\mathrm{a}}\end{array}$ & $\begin{array}{r}22.40 \pm \\
1.72^{\mathrm{a}}\end{array}$ & $\begin{array}{c}0.87 \pm \\
0.06^{\mathrm{a}}\end{array}$ & $\begin{array}{r}16.30 \pm \\
0.60^{\mathrm{a}}\end{array}$ & $\begin{array}{c}1.30 \pm \\
0.12^{\mathrm{a}}\end{array}$ & $\begin{array}{c}9.80 \pm \\
0.62^{\mathrm{a}}\end{array}$ & $\begin{array}{c}0.26 \pm \\
0.03^{\mathrm{a}}\end{array}$ & $\begin{array}{c}10.80 \pm \\
0.46^{\mathrm{a}}\end{array}$ & $\begin{array}{c}3.40 \pm \\
0.26^{\mathrm{a}}\end{array}$ & $\begin{array}{r}16.60 \pm \\
1.21^{\mathrm{a}}\end{array}$ & $\begin{array}{c}0.77 \pm \\
0.04^{\mathrm{a}}\end{array}$ \\
\hline $15^{\text {th }}$ day & $0.41^{\mathrm{a}}$ & $01^{a}$ & $120^{a}$ & $005^{a}$ & $\begin{array}{c}7.86 \pm \\
0.32^{\mathrm{a}}\end{array}$ & $\begin{array}{c}4.72 \pm \\
0.25^{\mathrm{a}}\end{array}$ & $\begin{array}{c}25.20 \pm \\
2.22^{\mathrm{a}}\end{array}$ & $\begin{array}{c}1.04 \pm \\
0.20^{b}\end{array}$ & $\begin{array}{c}18.76 \pm \\
0.42^{\mathrm{b}}\end{array}$ & $\begin{array}{l}1.01 \pm \\
0.099^{\mathrm{a}}\end{array}$ & $\begin{array}{c}6.26 \pm \\
0.30^{\mathrm{a}}\end{array}$ & $\begin{array}{c}0.44 \pm \\
0^{.03}\end{array}$ & $\begin{array}{c}9.77 \pm \\
0.40^{\mathrm{a}}\end{array}$ & $\begin{array}{c}3.90 \pm \\
0.12^{\mathrm{a}}\end{array}$ & $\begin{array}{c}23.60 \pm \\
1.500^{\mathrm{b}}\end{array}$ & $\begin{array}{c}0.87 \pm \\
\mathbf{0 . 0 3}^{\mathrm{a}}\end{array}$ \\
\hline
\end{tabular}

Means carrying different superscripts within the same column are significantly $(P \leq 0.05)$ different.

* In the control group (group I), all rats were sacrificed at day $10^{\text {th }}$. 

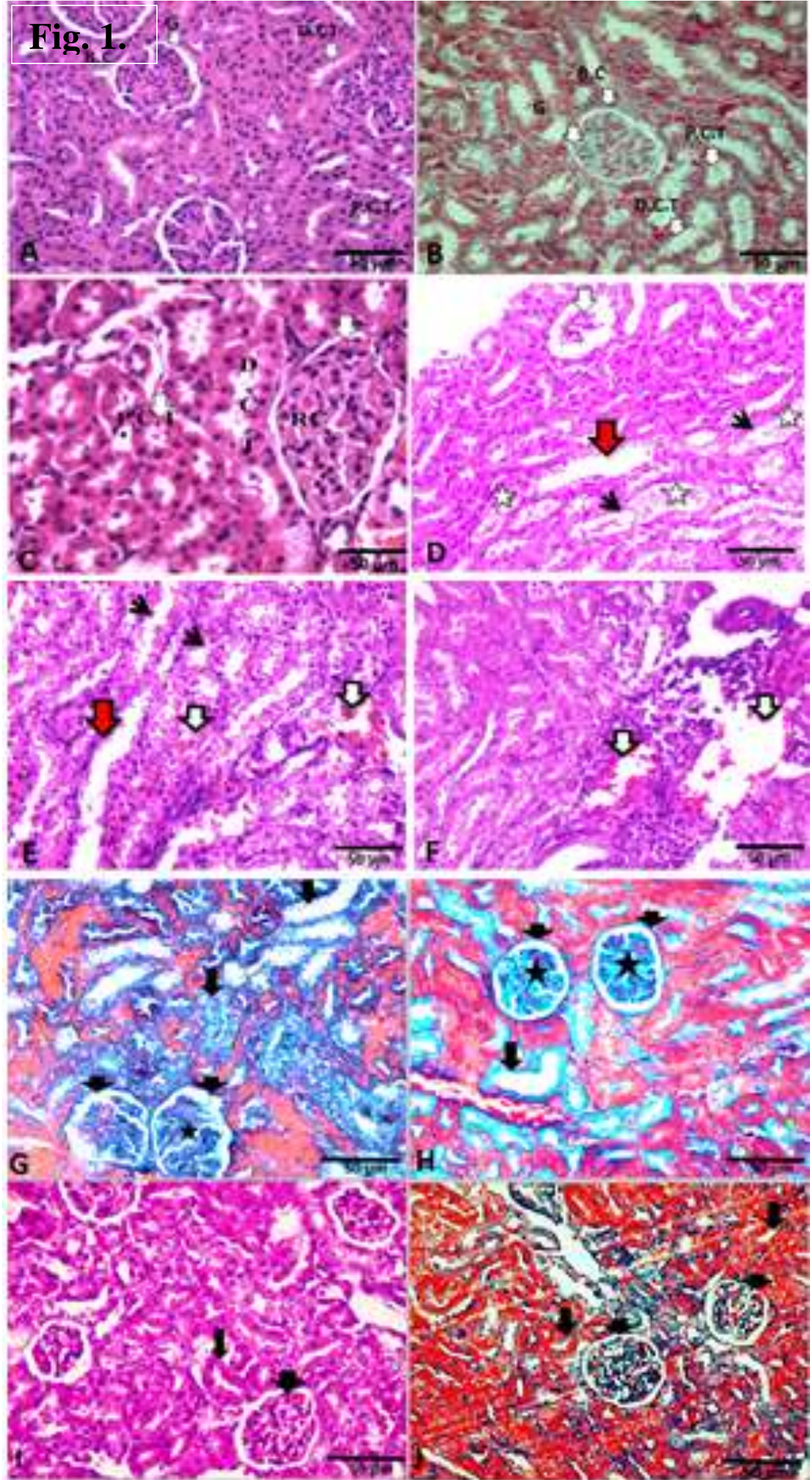


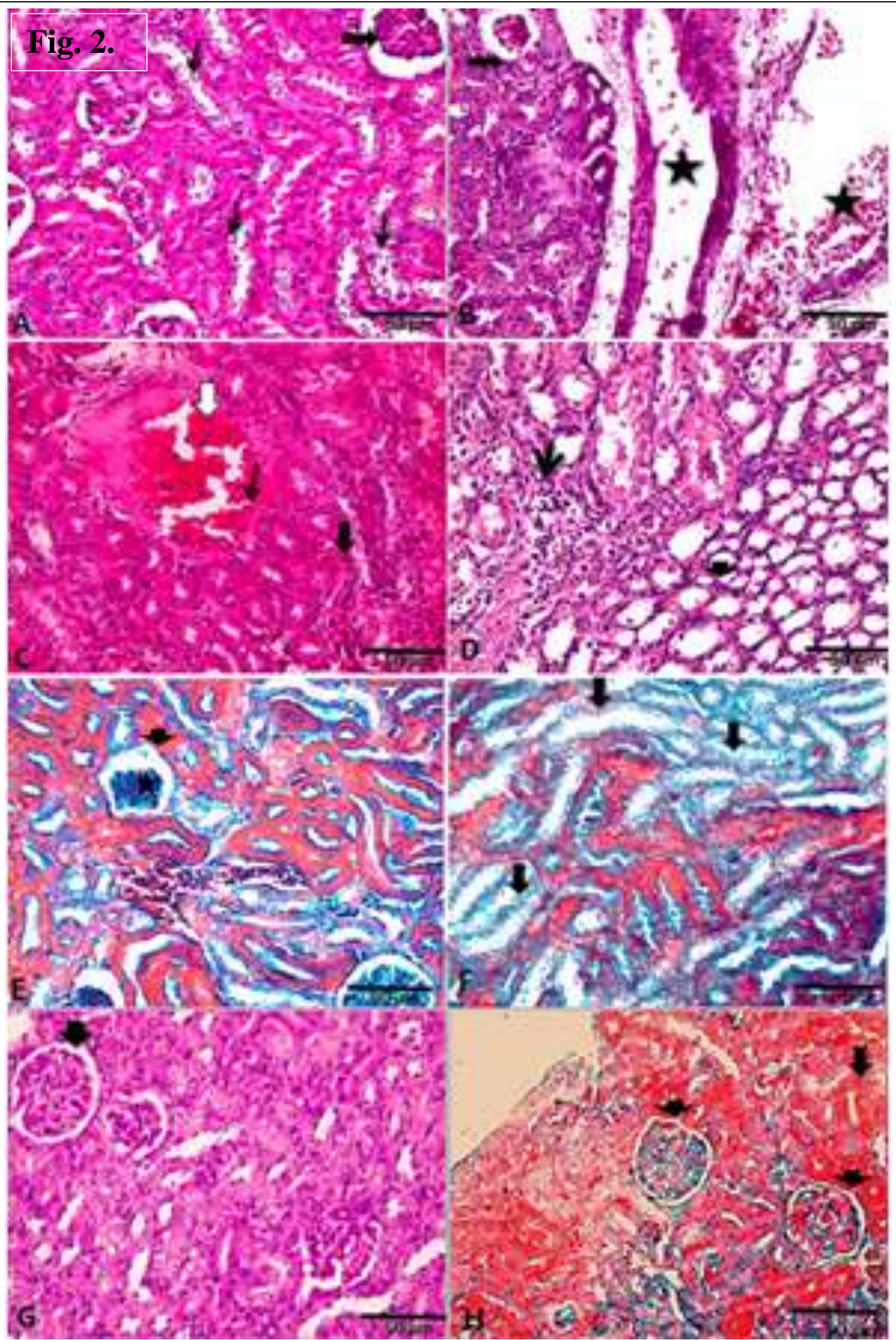


Fig.1. Light photo-micrographs of kidney sections from experimental groups after 10 days, represented, (Figs. a-c): normal control kidney sections from group I (a\&b) and group II (Fig. c) rats (Hx\&E), Showing normal glomerular corpuscle (G) and Bowman's capsule thickness (B.C), proximal (PCT) and distal convoluted tubules (DCT). (a and c ) Hx\&E, (b) Trichrome stain. The bar size was indicated in the pictures. (Figs. d-h): gentamicin control group III $(100 \mathrm{mg} / \mathrm{kg})$, showing moderate to severe nephrotoxic damage: Atrophic glomeruli (d). Tubular dilatation with evidence of epithelial cell desquamation (d\&e, red arrows), vacuolar appearance in tubular epithelium (d\&e, black arrow heads), with the presence of hyaline cast in renal tubular lumen (d, stars). Break down of glomerular capillaries and scattered hemorrhages were observed (e \& f, white arrows). Hx $\&$ E. (Figs. g-h): Masson's trichrome staining showing the pattern of collagen deposition (blue color), glomerular atrophy with collagen deposition in glomerulus and around Bowman's capsules causing its thickening ( $\mathrm{g} \& \mathrm{~h}$, arrow heads), necrosis of glomerular capillary tuft with deposited collagen (stars), marked collagen deposition inside or around tubules (tubule-interstitial fibrosis) (arrows). The bar size was indicated in the picture. (Fig.1I-J): moderate improvement of the histological structure in the form of decreased glomerular atrophy (i, arrow head), decrease in tubular and interstitial degeneration and necrosis (i, arrows), and decreased vascular damage. Hx \& E. (Fig. J): Lower degree of collagen staining with good cellular organization (without atrophic areas) and with normal B.C thickening ( $\mathrm{j}$, arrow heads) and also in tubules ( $\mathrm{j}$, arrows), Masson's trichrome staining. Bars $=50 \mu \mathrm{m}$ in all parts

Fig. 2. Representative Photomicrographs of kidney histomorphologic sections of experimental groups rats after 15 days. Group III rats showing sever nephrotoxic changes: (a-d): showing severe glomerular atrophy and necrosis (a \& b, thick arrows).Tubular epithelial necrosis and dilatation were observed (a, thin arrows). Vascular damage with sever hemorrhage (b, stars).Vascular congestion and thrombosis with fibrinoid degeneration around the blood vessels (c, white arrow), high lymphocytic cell infiltration (c \& d, black arrows). Hx \& E. (e-f) glomerular atrophy with collagen deposition in glomerulus and around Bowman's capsules causing its thickening (e \& f, arrow heads), marked collagen deposition inside or around tubules (tubule-interstitial fibrosis) (arrows). Masson's trichrome staining, the bar size was indicated in the pictures. (g-h): kidney sections of group IV rats showing marked decreased glomerular atrophy with good cellular configuration (g, arrow head), regeneration of tubular and interstitial degeneration epithelium Hx \& E. (h), showing minor collagen staining with good cellular organization (without atrophic areas) and with normal B.C thickening (h, arrow heads), in the tubules, collagen deposition was found, but not inside the epithelium (h, arrows). Masson's trichrome staining. Bars $=50 \mu \mathrm{m}$ in all parts. 


\section{Discussion}

Gentamicin is a charismatic antibiotic due to its chemical stability, fast bactericidal action, interaction with $\beta$ lactam antibiotics, little frequency of resistance, and virtual lower cost. Unfortunately, these advantages are frequently overs had owed by complications of nephrotoxicity and ototoxicity (Wargo and Edwards, 2014). The principal implicated side effect of therapeutic dosages of gentamicin is nephrotoxicity. It has documented that up to $30 \%$ of patients treated with GM for further than 7 days display some symptoms of nephrotoxicity (Adil et al., 2016). The damaging effect of GM were varying according to the circadian time of its administration (McKinney et al., 2015).

Renal damage is often expressed with an increase in serum levels of creatinine and urea nitrogen (Pai et al., 2012). It is well known that in muscles, creatine phosphate metabolism was established and gives rise creatinine as a non-protein byproduct of this process; creatinine is filtered by the kidney glomeruli normally. Contrariwise, the increased level of creatinine in the circulation might indicate failure in glomerular filtration rate and renal function (Vaidya et al., 2008). The elevated level of blood urea nitrogen is a well-manifestation of renal dysfunction as urea created by the liver is filtrated from blood by the kidney. (Arora et al., 2010). In the present study that rat's administered gentamicin exhibited a marked elevation in serum creatinine and BUN. Our obtained results imply the induction of nephrotoxicity with renal dysfunction in gentamicin administered rats. this result was in the same context with (Banday et al., 2008) who reported that gentamicin treatment daily for 15 days produced a significant elevation in serum creatinine, blood urea nitrogen while the highest increase was documented after 10 days of gentamicin administration.

The kidney dysfunction was observed to be associated with high renal oxidative stress as assessed in the form of a marked reduction in renal GSH. Moreover, a significant increase in renal lipid peroxidation as considered in the form of significant elevation in Malondialdehyde (MDA) was distinguished in gentamicintreated rats. These results confirm that gentamicin-induced nephrotoxicity is concurrent with induction of elevated renal oxidative stress. Gentamicin nephrotoxicity is supposed to be associated with the generation of reactive oxygen species as superoxide anion $\left(\mathrm{O}_{2}{ }^{-}\right)$, hydrogen peroxide (H2O2), and hydroxyl radical $\left({ }^{\circ} \mathrm{OH}\right)$ from renal cortical mitochondria, which is accompanying with an increase in lipid peroxidation and reduction in antioxidant enzymes (Randjelovic et al., 2017). So, the application of antioxidants hinders or inhibit cellular necrosis principally through their free radical destructing property (Lobo et al., 2010).

Wheat germ oil consider a natural antioxidant may possibly be effective in attempting to lower gentamicin nephrotoxicity as a result of its antioxidant characteristics (Kandeil et al., 2018). In our study we considered the renoprotective effect of wheat germ oil as antioxidants against oxidative stress damage and nephrotoxicity induced in rats by gentamicin throughout the estimation of renal function test on serum, oxidant and antioxidant markers and histological examination of renal tissue. Our results demonstrated the protective effect of wheat germ oil ( $1^{\text {st }} 10$ days with gentamicin $)$ and curative effect (last 5 days from stopping gentamicin injection by 10 days). 
Regarding renal function test, the results obtained from our study demonstrated that the serum creatinine and BUN level in the group II after 10 and 15 days were slightly decreased compared with normal control group, this result was agreed with (Gazar et al., 2016). While the Pretreatment group IV showed a significant reduction in serum creatinine and BUN levels at both 10 and 15 days as compared to gentamicin control group III. This result seemed similar to (Kandeil et al., 2018) who reported that wheat germ significantly ameliorated the elevated serum creatinine levels and BUN in comparison with gentamicin treated group at $\mathrm{p} \leq 0.05$. These results approve the protective and therapeutic curative influences of wheat germ oil.

Moreover, GM treatment in group III significantly decrease renal antioxidant activity as indicated by reduced renal tissue GSH content and CAT, and SOD activities. The effect was more significant at $15^{\text {th }}$ than at $10^{\text {th }}$ day. Conversely, rats in group IV showing significantly increase renal antioxidant activity as indicated by significant $(\mathrm{p} \leq 0.05)$ decrease in the renal lipid peroxidation; MDA content and significant $(\mathrm{p} \leq 0.05)$ increase in renal tissue GSH content and CAT, and SOD activities at 10 and 15 days as compared to gentamicin control group III. The effect was more significant $(\mathrm{p} \leq 0.05)$ at $15^{\text {th }}$ than at $10^{\text {th }}$ day in time dependent manner. These results indicate the reno-protective and antioxidant effects of WGO.

Regarding oxidative stress assessment, our results revealed that intra-peritoneal injection of GM (100 mg/kg. b. wt.) daily for 10 days significantly $(\mathrm{p} \leq 0.05)$ increased the renal lipid peroxidation; MDA level after 10 and 15 days as compared to normal control group. The effect was more drastic at $15^{\text {th }}$ than at $10^{\text {th }}$ day. This result was in agreement with (
Polat et al., 2006). Conversely, Our study showed that pretreatment of gentamicin treated rats with wheat germ oil afforded a significant reduction in MDA level and this result was confirmed by the findings of (Kandeil et al., 2018) who recorded a significant decrement in MDA level in gentamicin treated rats pretreated with wheat germ oil group. Our findings revealed that wheat germ oil afforded safe protective and curative effect against oxidative stress caused by gentamicin by reduction the elevation of MDA level.

Regarding antioxidants (enzyme and non-enzyme) assessment, Renal tissue GSH levels, CAT and SOD activities in group II rats after 10 and 15 days were increased significantly $(\mathrm{p} \leq 0.05)$ in compared with normal control group, this result was hand in hand with (Gazar et al., 2016, Kandeil et al., 2018). On the other side, in rats at group III; the CAT and SOD activity and GSH level were drastically decreased as compared to normal control group and this result was similar to (Abdel-Raheem et al., 2009) who documented that gentamicin produced a significant reduction in renal CAT and SOD activity and GSH level. Conversely, group IV rats elucidated a significant increase $(p \leq 0.05)$ in the renal tissue CAT and SOD activity and GSH level as compared to the gentamicin control group III and this obtained result was partially in accordance with (Kandeil et al., 2018) who reported that treatment with wheat germ oil could improve renal CAT level to their normal activity when compared to gentamicin control administrated group.

Our Results revealed that wheat germ oil afforded safe protective and curative effect through inhibition of free radicals that lead to the lipid peroxidation and oxidative stress by increasing the GSH level and CAT, SOD activity. 
In the present study, the histopathological lesions were recorded as glomerular atrophy with glomerulosclerosis, as the most prominent change in the cortex in group III.

The results of the present work revealed that tubular alterations were more noticeable in proximal convoluted tubules more than those observed in distal tubules in the form of tubular dilatation, epithelial cell desquamation, and vacuolar degeneration in addition to hyalinization casts observed inside tubular lumen and various location of collagen deposition. Similar findings have reported by (Mingeot-Leclercq and Tulkens, 1999). This possibly due to the piece of evidence that proximal convoluted tubules are the primary sets of reabsorption and active transport, thus leading to a greater concentration of gentamicin in the epithelial lining of these tubules. This may perhaps also propose that gentamicin nephrotoxicity is associated with its deposition in the proximal tubules. Renal cortex was more affected than the medulla. This might indicate that a considerably higher concentration of gentamicin reaches the cortex through the bloodstream than that arrive the medulla. This is in agreement with the findings of (Houghton et al., 1976).

Gentamicin administration induced severe abnormalities in the glomerulus and tubules in gentamicin control group III rats after 15 days of experimentation as compared to normal group rats. Glomerular atrophy with congestion of the glomeruli was distinct, this was confirmed on histopathological examination by (Shirwaikar et al., 2003). Significant changes in kidney tubules may be due to gentamicin reabsorption site in proximal convoluted tubules, resulting in degeneration and necrosis of the epithelial cells of the tubules. These findings are in concurrence with ( Ullah et al., 2013).

Pre-administration of WGO to GM treated rats presented in group IV expressive improvement in kidney glomeruli and tubules marked by the reduction of glomerular atrophy and reduction of renal tubular damage. In addition to, a lower degree of collagen staining with virtuous cellular configuration (without atrophic), than that observed in the gentamicin control group III, this is due to the protective and curative role of wheat germ oil against lipid peroxidation and oxidative stress which could suppress the inflammatory response induced by gentamicin (Hussein et al., 2014). Our recorded results confirmed that WGO is efficiently protected against gentamicin nephrotoxicity, and its cure effect after 15 days was much better than that observed after 10 days of experimental duration. This finding is confirmed by (Kandeil et al., 2018), who confirmed the renoprotective role of WGO against direct and indirect toxic effects of gentamicin on kidney within adjustment of BAX-BCL-2 gene expressions and additional inhibition of mitochondrial cytochrome c translocation into the cytosol (Kandeil et al., 2018).

\section{Conclusion}

In conclusion, this study may pave the way for the utilization and exploitation of WGO as sources of natural antioxidant. Our results showed that GM treatment induced alterations in rats sera related to nephrotoxicity, elevated lipid peroxidation and induced overproduction of free radicals in rat renal tissues indicating perturbed antioxidant defense system. Moreover WGO administration showed a significant protective effect against GMinduced nephrotoxicity due to its 
antioxidant effect and free radical scavenging activities.

\section{Acknowledgement}

The authors would like to express their deep thanks to Dr. Ahmed Elnahas, lecturer at the Department of Animal management, Faculty of Agriculture, Sohag University, Egypt for his help in achieving the statistical analysis of this study.

\section{References}

Abdel-Raheem IT, Abdel-Ghany AA, Mohamed GA (2009). Protective effect of quercetin against gentamicin-induced nephrotoxicity in rats. Biological and Pharmaceutical Bulletin, 32(1): 6167.

Abdel Fattah S, Fahim TM, El-Fatih N (2011). Prophylactic role of combined treatment with wheat germ oil and ginseng against radiation injury in male rats. Egyptian Journal of Hospital Medicine, 45(403): 415.

Abrams P, Hashim H, Tomson C, Macgowan A, Skews R and Warren $K$ (2017). The use of intravesical gentamicin to treat recurrent urinary tract infections in lower urinary tract dysfunction. Neurourology and urodynamics, 36(8): 2109-2116.

Adil M, Kandhare AD, Dalvi G, Ghosh P, Venkata S, Raygude KS, Bodhankar SL (2016). Ameliorative effect of berberine against gentamicininduced nephrotoxicity in rats via attenuation of oxidative stress, inflammation, apoptosis and mitochondrial dysfunction. Renal failure, 38(6): 996-1006.
Aebi H (1984). Catalase in vitro. Methods Enzymol, 105: 121-126.

Alessandri C, Pignatelli P, Loffredo L, Lenti L, Del Ben M, Carnevale R, Perrone A, Ferro D, Angelico F and Violi F (2006). Alpha-linolenic acidrich wheat germ oil decreases oxidative stress and CD40 ligand in patients with mild hypercholesterolemia.

Arteriosclerosis, thrombosis, and vascular biology, 26(11): 2577-2578.

Ali S, Rizvi S, Muzaffar S, Ahmad A, Ali A, Hassan S (2003). Renalcortical necrosis: a case series of nine patients \& review ofliterature. J Ayub Med Coll Abbottabad, 15: 4144.

Altucci P, Sapio U, Esposito E (1965). Gentamicin: antibacterial activity in vitro and clinical studies. Chemotherapy, 10(5): 312-320.

Arora M, Reddy K, Balakumar P.(2010). The low dose combination of fenofibrate and rosiglitazone halts the progression of diabetes-induced experimental nephropathy. Europian Journal of Pharmacology, 636(1-3): 137-144.

Bacha JWJ, Bacha LM (2012). Color atlas of veterinary histology, John Wiley $\&$ Sons. 3rd Ed.

Bancroft JSD, Turner DR (1996). Theory and Practice of Histological tequniques. Pearson Professional limited. London, U.K. 4 th Ed.

Banday AA, Farooq N, Priyamvada S, Yusufi ANAN, Khan F (2008). Time dependent effects of gentamicin on the enzymes of carbohydrate metabolism, brush border membrane and oxidative stress in rat kidney 
tissues. Life sciences 82(9-10): 450459.

Barakat A, Abbas OA, Ayad S, Hassan AM (2011). Evaluation of radioprotective effects of wheat germ oil in male rats. Journal of Animal Science, 7(2): 664-673.

Beutler E, Duron O, Kelly M (1963). Colorimetric method for determination of glutathione reduced. Journal of Laboratory and Clinincal Medicine, 61: 882.

Carleton HM, Drury RAB, Wallington EA (1980). Carleton's histological technique, Oxford University Press, USA.

Cekmen M, Otunctemur A, Ozbek E, Cakir S, Dursun M, Polat E (2013). Pomegranate extract attenuates gentamicin-inducednephrotoxicity in rats by reducing oxidative stress. Ren Fail. 2013: 268-274.

Coulombe J, Favreau L (1963). A new simple semimicro method for colorimetric determination of urea. Clinical chemistry, 9(1): 102-108.

Doolan P, Alpen E, Theil G. (1962). A clinical appraisal of the plasma concentration and endogenous clearance of creatinine. The American journal of medicine, 32(1): 65-79.

El-Hameed AA, Soliman HA, El-Reheem EA (2013). Protective Role of Wheat Germ Oil in Clozapine-Induced Oxidative Stress and Biochemical Alterations in Liver of male albino rats .Journal of American Science, 9(1): 268-274.

Field R, Verghese M, Walker L, Panala V, Shackelford L, Boateng J (2008). Feeding wheat germ meal and wheat germ oil reduced azoxymethaneinduced aberrant crypt foci in fisher 344 male rats. International Journal of Cancer Research, 4(4): 127-136.

Findlay M, Isles C (2015). Structure and Function of the Kidney. Clinical Companion in Nephrology. Cham, Springer International Publishing: 39.

Fujiwara K, Shin M, Matsunaga H, Saita T, Larsson LI (2009). Lightmicroscopic immunocytochemistry for gentamicin and its use for studying uptake of the drug in kidney. Antimicrobial agents and chemotherapy, 53(8): 3302-3307.

Gazar AA, Fahmy HA, Mohamed OS (2016). Possible effect of wheat germ oil or beta-carotene to enhance kidney recovery processes in irradiated rats. International Journal of Research Pharmacological Science, 7(4), 266-273.

Houghton DC, Hartnett M, cambellBoswell M, Porter G, Bennett W. (1976). A light and electron microscopic analysis of gentamicin nephrotoxicity in rats. American Journal of Pathology, 82: 589-612.

Hussein SA, Abdel-Aal S, Elghwab A (2014). Biochemical role of wheat germ oil on biomarkers of oxidative stress and inflammatory response in a rat model of endotoxemia. Benha Veterinary Medicine Journal, 27: 157-167.

Irmak S, Dunford NT (2005). Policosanol contents and compositions of wheat varieties. Journal of agricultural and food chemistry, 53(14): 5583-5586.

Kandeil MA, Hassanin KM, Mohammed ET, Safwat GM, Mohamed DS 
(2018). Wheat germ and vitamin $\mathrm{E}$ decrease $\mathrm{BAX} / \mathrm{BCL}-2$ ratio in rat kidney treated with gentamicin. Beni-Suef University Journal of Basic and Applied Science, 7(3): 257-262.

Karabacak M, Kanbur M, Eraslan G, Sarica ZS (2011). The antioxidant effect of wheat germ oil on subchronic coumaphos exposure in mice. Ecotoxicology and environmental safety, 74(7): 21192125 .

Kei S (1978). Serum lipid peroxide in cerebrovascular disorders determined by a new colorimetric method. Clinica chimica acta, 90(1): 37-43.

Khan MR, Badar I, Siddiquah A (2011). Prevention of hepatorenal toxicity with Sonchus asper in gentamicin treated rats. BMC complementary and alternative medicine, 11(1): 113.

Lobo V, Patil A, Phatak A, Chandra N. (2010). Free radicals, antioxidants and functional foods: Impact on human health. Pharmacognosy reviews, 4(8): 118.

McKinney W, Yonovitz A, Smolensky MH (2015). Circadian variation of gentamicin toxicity in rats. The Laryngoscope, 125(7): 252-256.

Mingeot-Leclercq MP, Tulkens PM (1999). Aminoglycoside nephrotoxicity. Antimicrob. Agents Chemother, 43(5): 1003-1012.

Nagai J, akano M. (2004). Molecular aspects of renal handling ofaminoglycosides and strategies for preventing thenephrotoxicity, Drug Metab Pharmacokinet Journal 19: 159-170.
Nale L, More P, More B, Ghumare B, Shendre S, Mote C. (2012). Protective effect of Carica papaya L. seed extract in gentamicin induced hepatotoxicity and nephrotoxicity in rats. International Journal Pharmcological Biological Science, 3: 508-515.

Nishikimi M, Appaji N, Yagi K (1972). The occurrence of superoxide anion in the reaction of reduced phenazine methosulfate and molecular oxygen. Biochemistry Biophyics Research Communication, 46(2): 849-854.

Noorani A, Gupta K, Bhadada K, Kale M. (2011). Protective effect of methanolic leaf extract of Caesalpinia bonducl on gentamicininduced hepatotoxicity and nephrotoxicity in rats. Iran Journal Pharmacological Therories, 10: 2125.

Ohkawa H, Ohishi N, Yagi K (1979). Assay for lipid peroxides in animal tissues by thiobarbituric acid reaction. Analytical biochemistry, 95(2): 358-351.

Pai P, Chamari Nawarathna S, Kulkarni A, Habeeba U, Reddy C. S, Teerthanath S. and et al. (2012). Nephroprotective effect of ursolic Acid in a murine model of gentamicin-induced renal damage. ISRN Pharmaco, 410902.

Patel Manali B, Deshpande S, Shah G. (2011). Evaluation of efficacy of vitamin $\mathrm{E}$ and $\mathrm{N}$-acetyl cysteine in gentamicin-induced nephrotoxicity in rats. Ren Fail, 33(3): 341-347.

Paterson DL, Robson JMB, Wagener MM (1998). Risk Factors for Toxicity in Elderly Patients Given Aminoglycosides Once Daily. 
Journal of General Internal Medicine 13(11): 735-739.

Polat A, Parlakpinar H, Tasdemir S, Colak C, Vardi N, Ucar M, Emre MH, Acet A (2006). Protective role of aminoguanidine on gentamicininduced acute renal failure in rats. Acta Histochemica, 108(5): 365-371.

Ramsammy L, Ling KY, Josepovitz C, Levine R, Kaloyanides GJ (1985). Effect of gentamicin on lipid peroxidation in rat renal cortex. Biochemical pharmacology, 34(21): 3895-3900.

Randjelovic P, Veljkovic S, Stojiljkovic N, Sokolovic D, Ilic I (2017). Gentamicin nephrotoxicity in animals: Current knowledge and future perspectives. EXCLI journal, 16: 388 .

Saleh ZA, Ibrahim KS, Farrag AR, Shaban EE (2010). Effect of carrot and wheat germ oil supplementation on antioxidant status of rats exposed to benzene. Polish Journal of Food and Nutrition Sciences, 60(2):175-181.

Sereno J, Vala H, Nunes S, Rocha-pereira $\mathrm{P}$, Carvalho E, Alves R, Teixeira F, Reis F (2015). Cyclosporine ainduced nephrotoxicity is ameliorated by dose reduction and conversion to sirolimus in the rat. Journal of physiology and pharmacology, 66(2): 285-299.

Shirwaikar A, Malini S and Kumari S. (2003). Protective effect of Pongamia pinnata flowers against cisplatin and gentamicin induced nephrotoxicity in rats Indian Journal of Experimental Biology 41(1): 5862.

Smith CR, Lipsky JJ, Laskin OL, Hellmann DB, Mellits ED, Longstreth J, Lietman PS (1980). Double-blind comparison of the nephrotoxicity and auditory toxicity of gentamicin and tobramycin. New England Journal of Medicine, 302(20): 1106-1109.

Testa R, Tilley B (1976). Biotransformation, a new approach to aminoglycoside biosynthesis: II Gentamicin. The Journal of antibiotics, 29(2): 140-146.

Ullah N, Khan M, Khan T, Ahmad W (2013). Protective effect of Cinnamomum tamala extract on gentamicin-induced nephrotic damage in rabbits. Tropical Journal of Pharmcological Research, 12: 215-219.

Vaidya V, Ferguson M, Bonventre J (2008) Biomarkers of Acute Kidney Injury. Annual Review of Pharmacology and Toxicology, 48: 463-493.

Wargo K, Edwards J. (2014). Aminoglycoside-Induced Nephrotoxicity. Journal of Pharmcological Practice 27(6): 573-577.

Wu Y, Connors D, Barber L, Jayachandra S, Hanumegowda UM, Adams SP (2009). Multiplexed assay panel of cytotoxicity in $\mathrm{HK}-2$ cells for detection of renal proximal tubule injury potential of compounds. Toxicology in Vitro, 23(6): 11701178. 